\title{
Pekarangan: Pendidikan Karakter melalui Kegiatan Keagamaan
}

\author{
Ginda Tia Monika'), Rafika Febrilia' ${ }^{2)}$, Yofita Feganandia Kumala ${ }^{3)}$ \\ 1,2,3)Fakultas Keguruan dan Ilmu Pendidikan \\ Universitas Muhammadiyah Surakarta \\ a220170058@student.ums.ac.id \\ doi: $x x x$ xxx xxx
}

\begin{abstract}
Abstrak: Permasalahan yang ada pada negara kita dalam pendidikan adalah kurangnya pengaruh pendidikan karakter yang telah di ajarkan kepada peserta didik, bisa kita lihat pada sekarang banyak sekali kasus yang menyangkut pelanggaran-pelanggaran menyangkut nilai dan moral yang dilakukan oleh peserta didik seperti pelecehan seksual, pemakaian narkoba, miras dll. Oleh karena itu, kegiatan keagamaan secara tidak langsung dapat menjadi salah satu solusi dalam memberikan pendidikan karakter pada anak, karena di dalamnya akan dibubuhi permasalahan serta solusi dalam kehidupan sehari-hari.

Melalui metode observasi dan wawancara dengan siswa maupun tenaga pendidik di SMP Muhammadiyah 8 Surakarta, diperoleh cara semacam ini efektif dalam memberikan pembelajaran mengenai sikap maupun tingkah laku anak, anak akan lebih mudah mencermati sebab dikaitkan dengan aktifitas religiusnya masingmasing.
\end{abstract}

Kata kunci : pendidikan karakter,sikap,religius,pembelajaran

\section{Pendahuluan}

Secara sederhana, pendidikan karakter dapat didefinisikan sebagai segala usaha yang dapat dilakukan untuk mempengaruhi karakter siswa. Tetapi untuk mengetahui pengertian yang tepat, dapat dikemukakan di sini definisi pendidikan karakter yang disampaikan oleh Thomas Lickona. (Lincoln 1991) menyatakan bahwa pengertian pendidikan karakter adalah suatu usaha yang disengaja untuk membantu seseorang sehingga ia dapat memahami, memperhatikan, dan melakukan nilai-nilai etika yang inti. Kekuatan karakter akan terbentuk dengan sendirinya jika ada dukungan dan dorongan dari lingkungan sekitar. Peran keluarga, sekolah, dan masyarakat sangat dominan dalam mendukung dan membangun kekuatan karakter.Oleh karena itu, sangat riskan seorang anak tanpa adanya pendidikan karakter dalam hidupnya. Aspek mengembangkan karakter bukan hanya melalui panduan paten sebuah buku, namun banyak sumber dan objek yang dapat dijadikan objek pembelajaran. Salah satunya kegiatan keagamaan. Di SMP Muhammadiyah 8 Surakarta setiap pagi sebelum Kegiatan Belajar Mengajar (KBM) 
berlangsung semua siswa diwajibkan untuk shalat dhuha, tadarus AlQuran, pembelajaran akhlaq, fiqih maupun diskusi terkait persoalan yang banyak dihadapi remaja saat itu. Dari kebiasaan yang selalu dilakukan tersebut mendorong siswa menjadi siswa yang disiplin, tanggung jawab dan menjadi pribadi yang taat dalam beragama.

Tujuan daripada kegiatan ini adalah yang utama manjadikan anak sebagai pribadi yang baik bukan hanya dibidang akademis namun juga di bidang keagamaan. Dengan kebiasaan seperti ini, para pendidik SMP Muhammadiyah 8 Surakarta mengharapkan saat menerima pembelajaran duniawi siswa lebih siap dan tenang. Akan selalu ingat terhadap Tuhan-Nya sehingga menghindari perbuatan yang tidak sesuai pada jalurnya. Terbukti dengan kebiasaan ini banyak dicetak siswa-siswi yang berprestasi, sopan dan santun.

Tujuan pendidikan karakter yakni pembentukan kepribadian manusia yang baik. Pendidikan karakter adalah memfasilitas penguatan dan pengembangan nilai-nilai tertentu sehingga terwujud dalam perilaku anak, baik ketika proses sekolah maupun setelah proses sekolah (setelah lulus dari sekolah).

Pendidikan karakter bertujuan meningakatkan mutu penyelenggaraan hasil pendidikan di sekolah yang mengarahkan pada pencapaian pembentukan karakter dan akhlak mulia peserta didik secara utuh, terpadu, dan seimbang sesuai dengan standar kompetensi kelulusan. Melalui pendidikan karakter ini diharapkan peserta didik mampu secara mandiri meningkatkan dan menggunakan pengetahuannya, mengkaji dan menginternalisasi serta mempersonalisasi nilai-nilai karakter dan akhlak mulia sehingga terwujud dalam perilaku sehari-hari.

Pendidikan karakter ini lebih mengutamakan pertumbuhan individu yang ada dalam pendidikan. Pendidikan karakter satu kesatuan yang tidak dapat dipisahkan. Pendidikan karakter dapat terapkan melalui kegiatan keagamaan yaitu: sholat dhuha di laksanakan setiap hari sebelum memulai kegiatan KBM, Tadarus AlQuran setelah melaksanakan sholat dhuha, PPA yang dilaksanakan setiap hari selasa, sholat dzuhur dan ashar yang di laksanakan secara berjamaah di masjid sekitar.

Dalam kegiatan keagamaan di SMP Muhammadiyah 8 Surakarta harus ditunjang dengan atau pembiasaan tentang sikap yang baik dalam menanamkan pendidikan karakter terhadap siswa. Dengan kegiatan keagamaan yang nantinya dapat mewujudkan peserta didik yang berakhlakul karimah. 


\section{Metode}

a. Jenis penelitian

Pendekatan yang dilakukan dalam penelitian ini menggunakan pendekatan kualititatif dengan jenis diskriptif. Penelitian deskriptif (descriptive reseach) ditujukan untuk mendeskripsikan suatu keadaan atau fenomena-fenomena apa adanya. Alasan menggunakan jenis penelitian kualitatif deskriptif ini karena peneliti ingin mendeskripsikan atau menggambarkan secara apa adanya tentang praktik pelaksanaaan pendidikan karakter di SMP Muhammadiyah 8 Surakarta.

b. Sumber data

Responden dipilih dari orang-orang yang dianggap mampu memberikan informasi mengenai latar belakang dan keadaan yang sebenarnya dari objek yang diteliti sehingga data yang dihasilkan dapat akurat. Dalam penelitian kualitatif sumber data yang dipilih dengan cara purposive, yaitu dipilih dengan pertimbangan dan tujuan tertentu (Sugiyono 2008, 216). Pertimbangan yang diambil dalam penelitian ini adalah sumber data yang melibatkan orangorang dalam pelaksanaan pendidikan karakter di SMP Muhammadiyah 8 Surakarta. Sumber data yang memenuhi pertimbangan tersebut adalah pengelola kesiswaan yitu wakil kepala sekolah bagian kesiswaan (WKS 3) beserta staf, guru, karyawan dan peserta didik.

c. Teknik pengumpulan data

1) Observasi

Observasi adalah pengamatan langsung terhadap objek penelitian. Metode observasi digunakan dalam penelitian ini adalah observasi pasif, dimana peneliti dalam melakukan pengamatan tidak terlibat dalam kegiatan tersebut. Observasi dalam penelitian ini ditujukan untuk melihat dan menggambarkan situasi dari pelaksanaan pendidikan karakter di SMP Muhammadiyah 8 Surakarta.

2) Wawancara

Adalah salah satu metode pengumpulan data dengan jalan komunikasi yaitu melalui kontak atau hubungan pribadi antara pengumpulan data (pewawancara) dengan sumber data (informan). Wawancara berupa percakapan dengan maksud tertentu yang dilakukan oleh dua pihak yaitu pewawancara 
(interviewer) yang mengajukan pertanyaan (interviewee). Disini peneliti berencana mewawancarai beberapa responden atau informan diantaranya, kepala sekolah, guru agama, serta guru yang bertugas sebagai koordinator kegiatan keagamaan di SMP Muhammadiyah 8 Surakarta.

3) Dokumentasi

Dokumentasi adalah metode pengumpulan data yang diperoleh dari hasil laporan dan keterangan secara tertulis,tergambar,terekam ataupun tercetak. Teknik ini digunakan untuk mendapatkan data pendukung penelitian. Data tersebut antara lain profil sekolah, dokumen-dokumen mengenai pelaksanaan Pendidikan karakter melalui keagamaan sekolah dan gambar-gambar atau foto-foto situasi dari kegiatan, dll.

Instrumen yang dipakai dalam penelitian ini adalah human instrument. Peneliti sebagai human instrument mengumpulkan data dari observasi, wawancara, dan dokumentasi. Selain itu Peneliti sebagai human instrument, berfungsi menetapkan fokus penelitian, memilih informan sebagai sumber data,melakukan pengumpulan data,menilai kualitas data, menafsirkan data dan membuat kesimpulan atas temuannya.

Pengambilan data pada penelitian kualitatif dilakukan secara berulang-ulang (iteration) sampai dirasakan jenuh (redundancy) atau sampai dirasakan jawaban yang didapat hamper sama.seperti yang dikatakan oleh (Lincoln and Guba 1985, 188) "The Iteration are repeated a softenas necessary until redundancy is achived." Pengambilan data dikatakan sudah jenuh apabila data yang didapat tidak bertambah meskipun peneliti sudah menambah jumlah responden.

\section{d. Teknik Analisis Data}

Setelah data terkumpul tahap selanjutnya adalah mengolah data dan menganalisis data.Data yang diperoleh kemudian dianalisis secara deskriptif kualitatif yaitu dengan cara menghimpun fakta dan mendeskripsikannya. Secara lebih lanjut menurut (Sukardi 2007, 86), mendeskripsikan data kualitatif dilakukan dengan cara menyusun dan mengelompokkan data yang ada, sehingga memberikan gambaran nyata terhadap sumber data.Analisis ini dilakukan pada seluruh data yang diperoleh dari hasil wawancara,observasi dan dokumentasi. 


\section{Hasil dan Pembahasan}

Penelitian ini menyajikan tentang menanamkan pendidikan karakter di SMP Muhammadiyah 8 Surakarta yang melalui kegiatan keagamaan. Sebagai utama dan terpenting yang harus di jalankan oleh peserta didik dalam kehidupan sehari sehari maupun di lingkungan masyarakat setempat sebagai sekolah yang menerapkan agama sebagai dasar pembelajaran yang sudah menjadi budaya di SMP Muhammadiyah 8 Surakarta, yaitu :

a. Membiasakan shalat dhuha dan membaca doa pagi sebelum mengawali aktivitas.Ini memberikan gambaran bagaimana peserta didik mampu mengembangkan karakter dari dirinya sendiri untuk bersikap disiplin dan tanggung jawab.

b. Dilanjutkan tadarus al-qur'an yang mengajarkan kepada siswa ketaqwaan dan para guru memberikan penjelasan arti atau terjemahan surah yang dibaca.

c. Pembelajaran Akhlaq, para guru memberikan motivasi, wawasan terkait perilaku remaja agar para siswa dapat meningkatkan akhlakul karimah agar peserta didik memiliki pengetahuan dan penghayatan yang benar terhadap hal-hal yang diimani.

d. Pembelajaran fiqih yaitu salah satu upaya dari guru SMP Muhammadiyah 8 Surakarta untuk meningkatkan ketaatan terhadap ajaran islam sebagai pedoman atau pegangan hidup. Dalam realisasinya materi yang dibawakan guru setelah sholat dhuha salah satunya, tentang Najis, hadas dan cara mensucikannya.

Dalam pembentukan karakter sesuai budaya islam tentu tidak semata mata hanya dilakukan di sekolah melalui kegiatan belajar mengajar melainkan juga melalui pembiasaan (habituation) di luar sekolah, seperti: religius, jujur, disiplin, tolerasi, kerja keras, cinta damai, tolong menolong, tanggung jawab, dan punya rasa malu ketika bersalah. Oleh karena itu, guru memiliki peranan yang sangat penting untuk mengembangkan pendidikan karakter dimana seorang guru sebagai contoh untuk peserta didik. Dan peran sekolah memiliki peranan besar dalam faktor pendukung dalam pengembangkan pendidikan karakter karena peran sekolah sebagai pusat pembudayaan dalam pengembangan budaya sekolah (school culture).

Penelitian ini mefokuskan diri pada studi kasus millennial yang kerap sebagai pemicu kenakalan remaja. Menurut (Maryadi 2010, 13), "subjek penelitian mencakup semua pihak yang dapat memberikan 
informasi yang di perlukan dalam penelitian ini “. Subjek penelitian ini adalah kepala sekolah, guru, dan siswa. Objek penelitian, Menurut (Maryadi 2010,13), objek penelitian ini adalah "variabel yang di teliti, baik berupa peristiwa, tingkah laku, aktifitas, atau gejal -gejala sosial lainnya ". Objek penelitian adalah variabel yang di teliti yaitu kebiasaan dalam beretika dan bermoral di sekolah.

Menurut (Patilima 2005, 88), “data kualitatif diperoleh dari hasil pengumpulan data dan informasi dengan menggunakan metode pengumpulan data seperti pengamatan, wawancara, menggambar, diskusi kelompok, dan lain - lain“.

Sumber data utama dalam penelitian yang bersifat kualitatif berupa kata - kata atau tindakan yang didapat dari mengamati suatu peristiwa kemudian dibuat catatan lapangan dan di lanjutkan dengan catatan penelitian. Berdasarkan sumber di atas adalah sebagai berikut:

a. Tempat dan Peristiwa Observasi

b. Informan

c. Arsip atau Dokumen

Berdasarkan hasil pengamatan, teknik pengumpulan data antara lain wawancara, observasi, dan dokumentasi.

Upaya - upaya menanamkan karakter pada peserta didik di SMP Muhammadiyah 8 Surakarta sudah di lakukan ketika mereka memasuki kawasan sekolah setelah itu siswa di latih untuk menghormati guru beserta karyawan dan orang yang lebih tua dari mereka dengan cara memberi salam dan mencium tangan kegiatan itu sudah dilakukan dan sudah menjadi budaya di SMP Muhammadiyah 8 Surakarta untuk melatih siswa dalam menghadapi masyarakat. Dan mempunyai etika dan moral yang baik bahkan menumbuhkan rasa hormat pada orang yang lebih tua ketika sudah lulus dari SMP Muhammadiyah 8 Surakarta.

1. Observasi Kelas

a. Observasi kelas, sampel yang digunakan adalah kelas VII C, VIII A, dan VIII C. 
Tabel 1. Hasil Observasi

\begin{tabular}{|l|l|l|}
\hline NO & KELAS & HASIL PENELITIAN \\
\hline 1. & Vll C & $\begin{array}{l}\text { Siswa-siswinya memiliki semangat belajar yang } \\
\text { tinggi dalam pembelajaran pendidikan Pancasila } \\
\text { dan Kewarganegaraan dan menghargai seorang } \\
\text { guru dan hanya beberapa siswa yang mau } \\
\text { memperhatikan guru ketika mengajar, tetapi } \\
\text { banyak guru lain yang mengisi di kelas tersebut } \\
\text { merasa resah karena terkadang muridnya membuat } \\
\text { keributan di kelas, seperti: ngobrol sendiri, lari } \\
\text { kesana kemari, dan } \\
\text { lain-lain. }\end{array}$ \\
\hline 2. & Vlll A & $\begin{array}{l}\text { Siswa-siswinya memiliki semangat belajar yang } \\
\text { tinggi dalam pembelajaran pendidikan Pancasila } \\
\text { dan Kewarganegaraan dan menghargai seorang } \\
\text { guru, } \\
\text { aktif dalam belajar, kondusif, dan memperhatikan } \\
\text { guru ketika mengajar, menerangkan di depan. }\end{array}$ \\
\hline 3. & Vlll C & $\begin{array}{l}\text { Kelas yang paling gaduh dibandingkankelas } \\
\text { lainnya, namun ada beberapa siswa yang } \\
\text { memperhatikan guru ketika mengajar, dan hanya } \\
\text { sedikit siswa yang aktif. }\end{array}$ \\
\hline
\end{tabular}

Dari hasil pengamatan, metode pembelajaran menggunakan cara sebagai berikut:

1) Ceramah,

2) Tanya Jawab,

3) Pembelajaran Aktif,

4) Penugasan ( meringkas buku paket)

5) Diskusi Kelompok

Pada kegiatan rutin untuk nilai karakter religius yang dikembangkan, berupa: (1) melaksanakan solat dhuha dan doa pagi untuk mengawali aktivitas, menghafal asmaul husnah yang dipimpin oleh guru agama. (2) melaksanakan solat dhuhur dan ashar berjamaah di masjid. (3) setiap hari jum'at melaksanakan solat jum'at di masjid bagi pria. (3) siswa di minta mengucapkan salam sebelum dan sesudah kegiatan, jika bertemu dengan guru, bicara dan bertindak dengan sopan santun. (4) siswa dibiasakan untuk mengucapkan terima kasih, maaf, permsi dan tolong. (8) mengetuk pintu sebelum masuk ke dalam ruangan orang lain. (9) meminta izin menggunakan barang orang lain. 


\section{Simpulan}

Hasil penelitian ini menunjukkan bahwa penanaman karakter siswa bisa diterapkan lewat pendidikan Agama Islam dan pendidikan Pancasila dan Kewarganegaraan sebagai utama dan terpenting dalam kehidupan siswa di SMP Muhammadiyah 8 Surakarta. Dalam penelitan ini dapat disimpulkan beberapa hal berikut:

a. Penanaman karakter di SMP Muhammadiyah 8 Surakarta, diterapkan melalui kegiatan-kegiatan untuk melatih siswa saling bekerja sama dengan siswa lain, melatih siswa untuk menyelesaikan masalah dengan cara musyawarah asalkan dapat menghargai pendapat orang lain, melatih siswa untuk bersosialisasi di dalam maupun di luar lingkungan sekolah. Hal tersebut di wujudkan dengan kegiatan-kegiatan sebagai berikut: IPM (Ikatan Pelajar Muhammadiyah) adalah salah satu kegiatan yang berada di kemuhammadiyahaan yang dari SMP, dan SMA/SMK, HW (Hizbun Wathon) adalah salah satu kegiatan yang ada di SMP Muhammadiyah 8 Surakarta yang berguna untuk membentuk karakter siswa agar menumbuhkan kepribadian, akhlak mulia, dan bertanggung jawab kaum muda sehingga akan tercipta generasi penerus muhammadiyah yang baik.

b. Nilai-nilai Pancasila dan Keagamaan di sekolah diperlukan upaya agar dunia pendidikan mampu menjadikan manusia yang berkualitas dan melahirkan seorang pemimpin yang beriman, berakhlak, cerdas, memiliki ilmu pengetahuan dan keterampilan, keuletan serta wawasan masa depan dan fisik yang sehat.

\section{Daftar Pustaka}

Lincoln, and Guba. 1985. Naturalistic Inquiry. USA: Sage Publisher. Lincoln, Thomas. 1991. Educating for Character: How Our School Can Teach Respect and Responsibility. New York: Bantam.

Maryadi. 2010. Pedoman Penulisan Skripsi FKIP. Surakarta: FKIP

UMS. Patilima, Hamid. 2005. Metode Penelitian Kualitatif.

Bandung: PT. Raja Grafindo Perkasa.

Sugiyono. 2008. Metode Penelitian Kuatintatif, Kualitatif Dan R\&D. Bandung: CV. Alfabeta.

Sukardi. 2007. Metodologi Penelitian Pendidikan. Yogyakarta: Bumi Aksara. 